\title{
Engramy ciała: poetyka notek bólowych zachowanych w archiwum
}

\section{Aleksandra Wata}

Michalina Kmiecik

\author{
ORCID: 0000-0003-0118-3657
}

Doświadczenie archiwum to przede wszystkim doświadczenie gatunkowej niejednorodności i splątania. Uporządkowanie i skatalogowanie wszystkich form tekstowej obecności wydaje się zadaniem niemożliwym do wykonania ${ }^{1}$. Archiwum Aleksandra Wata, o którym będzie mowa, bardzo jaskrawo i radykalnie potwierdza tę tezę. I choć w roku 2010 zostało ono na nowo ułożone, a biblioteka Beinecke dołożyła wszelkich starań, by spuścizna Wata jawiła się w sposób jak najbardziej przejrzysty, wciąż - obcując z zachowanymi tam pudłami i teczkami - mamy wrażenie, że natykamy się na maszynopisy i rękopisy podzielone. Wiele kartek zostało przez pisarza (lub Olę Watową) ponumerowanych, jednak zawartość teczek poświadcza, iż części stron brakuje lub znajdują się w zupełnie innym miejscu. Dostajemy do rąk korpus rozczłonkowany, wewnętrznie porwany, niespójny. Jednocześnie owa skłonność archiwum do rozpraszania się, wytwarzania przestrzeni atopicznego nieukorzenienia, zdaje się idealnie pasować do charakteru Watowskiego zapisywania. Ma on bowiem tendencję do tworzenia swoich notesów, zapisków z drobnych fragmentów: niektóre z nich opatruje datą (ale często jedynie dzienną, bez podania roku), inne pozostawia jako luźne notatki. Niektóre stronice zapisuje wielokrotnie - znajdziemy na nich i szkice wierszy, i adresy bibliograficzne, i uwagi dotyczące stanu zdrowia.

Wszystkie teksty w notatnikach zachowały się w formie - jak stwierdzał Wat w zapisie z Kaiser Hospital z 11 września 1964 roku - „urwanej i żadnej (pozbawionej swego k kształtu u i wolumeni postaci, ktorym wypełniłem setki kartek strronic karteluszkow swistkow, bez pożytku, nie do odcyfrowania dniekiedy nawet sla mnie samego"2. Już sam cytowany fragment - pełen błędów literowych i skła-

\footnotetext{
${ }^{1} \mathrm{Na}$ temat teorii archiwów oraz doświadczenia ich lektury zob. m.in. Jacques Derrida, Gorq̨czka archiwów, tłum. Jakub Momro (Warszawa: Wydawnictwo IBL, 2016); Mateusz Antoniuk, „Proces tekstotwórczy jako najpiękniejszy przedmiot badań, którego nie ma”, w Pracownia Herberta. Studia nad procesem tekstotwórczym, red. Mateusz Antoniuk (Kraków: Wydawnictwo Uniwersytetu Jagiellońskiego, 2017), 11-26; monograficzny numer „Czasu Kultury” zatytułowany Archiwum prywatne (Czas Kultury 193, nr 2 [2017]).

${ }^{2}$ Beinecke Rare Book \& Manuscript Library (New Haven), Aleksander Wat Papers (GEN MSS 705), Series II: Writings, Box 28, Folder 662.
} 
dniowych - świadczy o roboczym, plastycznym charakterze tworzonych notatek. Ich „żadna forma” odsyła nas jednak przede wszystkim do stylistycznej miazgi, jaką z pewnością stanowią zapisy Wata - domagają się one zawsze współuczestnictwa, czułego czytelnika, który zrozumie je pomimo wszelkich skaz i niedoskonałości. Jednocześnie ustanawiają także nowe spojrzenie na możliwości genologicznego porządkowania. Z jednej strony - Wat postrzega je jako potencjalne części większych całości i planuje włączać je w rozmaite projekty: autobiografii ${ }^{3}$, Rapsodii politycznych czy powieści o Stalinie, dzienników (z archiwum wyłania się nie tylko idea diariusza, który później zostanie złożony przez Olę Watową w Dziennik bez samogłosek, ale także koncepcja dziennika magnetofonowego - niestety zachowało się jedynie kilka kartek, najpewniej przepisanych z taśmy, w Box 32, Folder 743-745). Z drugiej strony - ich „żadność, brak jasnych reguł tworzenia, mieszanie rozmaitych stylów, urywkowość uniemożliwiają genologiczne porządkowanie, rozumiane jako katalogowanie. Wyjściem z tej sprzeczności, a także propozycją, która ma szansę pomóc rozpoznać sens atopicznych archiwów, pozostaje redefinicja genologii w duchu poststrukturalnym: wydobywająca ideę zbiorów rozmytych, jedynie „pokrewnych” sobie, a nie opartych na zasadzie tożsamościowej. Jak słusznie bowiem zauważa Adam Dziadek, nawiązując do rozpoznań Jacques’a Derridy z Gorqczki archiwów:

archiwum to kwestia przyszłości. Archiwum jest miejscem tradycji, miejscem, w którym przeszłość kreuje teraźniejszość i przyszłość. To prawda, że wiąże się z odpowiedzialnością (etyka), z odpowiedzialnością za przyszłość, bo to od nas zależy, jaki nadamy kształt temu, co samo archiwum w sobie kryje ${ }^{4}$.

Czytając Watowskie zbiory, nie możemy zanegować ich przynależności do tradycji i historii; poeta bowiem nieustannie upomina się o miejsce dla swoich tekstów, o możliwość ich zaistnienia w przestrzeni kultury. Pisze, choć zdaje sobie sprawę z nieczytelności swoich notatek, aby uczynić swój głos słyszalnym, przywrócić sobie poczucie zagrabionej przez chorobę obecności. Jednocześnie nie potrafi swojego idiosynkratycznego doświadczenia, swojej „osobności” wtłoczyć w żadne konkretne ramy: granice genologiczne tekstów Wata pozostają rozmyte. Jak zatem opowiedzieć o radykalnej pojedynczości, zarazem okazując szacunek jej potrzebie przynależności? Przyszłość archiwum nie leży bowiem w zanegowaniu jego porządkującego charakteru i jego potrzeby współtworzenia tradycji. Przyszłość musi być plastyczna.

\section{Archiwum jako konstelacja zbiorów rozmytych}

Grzegorz Grochowski w Pamięci gatunków przejrzyście rekonstruuje związki poststrukturalnej genologii z koncepcją „pokrewieństwa rodzinnego” Ludwiga Wittgensteina. Jak trafnie konkluduje:

Podstawę przynależności do danego zakresu ma [...] stanowić nieregularny układ zazębiających się relacji między niektórymi składnikami, „skomplikowana siatka zachodzących na siebie i krzyżujących się podobieństw; podobieństw w skali dużej i małej”5.

\footnotetext{
${ }^{3} \mathrm{O}$ możliwości wpisania niektórych notatek Wata (np. zapisu z Kaiser Hospital) w projekt autobiografii heterotopicznej Moje więzienia - moje szpitale pisałam wcześniej - zob. Michalina Kmiecik, „Zapiski z Kaiser Hospital Aleksandra Wata - fragmenty autobiografii heterotopicznej”, Wielogłos 31, nr 1 (2017): 67-86.

${ }^{4}$ Adam Dziadek, „Aleksander Wat w Beinecke Library w Yale”, Teksty Drugie, nr 6 (2009): 257.

${ }^{5}$ Grzegorz Grochowski, Pamięć gatunków. Ponowoczesne dylematy atrybucji gatunkowej (Warszawa: Wydawnictwo IBL, 2018), 52.
} 
Już przywoływany przez niego cytat z Dociekań filozoficznych obrazuje, iż gatunki działają na wzór siatki nakładających się na siebie cech czy wyznaczników. Każdy tekst może stykać się $\mathrm{z}$ rozmaitymi jej nitkami, elastycznie zmieniając swoje położenie w obrębie pola relacji. Moglibyśmy więc powiedzieć za Stanisławem Balbusem, że współcześnie - mając do czynienia z ogromem tekstów celowo przełamujących tradycyjne schematy gatunkowe - powinniśmy odejść od genologii w ujęciu taksonomicznym i zajmować się generowanym w jej ramach

zróżnicowanym polem genologicznych odniesień, odniesień na ogół wielowartościowych, tak jak właśnie wielowartościowe, wieloaspektowe i niejednoznaczne - a przez to zmierzające ku samolikwidacji - wydają się dziś wielu teoretykom literatury gatunkowe kwalifikacje. Gatunek literacki danego „hipertekstu” nie ma w takim ujęciu żadnego „obowiązku” realizacji jakiegokolwiek gatunkowego paradygmatu - choćby i w sensie negatywnym [...]. Musi natomiast - na różne sposoby - wskazywać na rozmaite punkty genologicznych odniesień. Rzecz w tym, że owych punktów może być wiele i nie muszą one bynajmniej pozostawać ze sobą w stosunkach komplementarnych uzgodnień ${ }^{6}$.

Pożyczona od Gérarda Genette’a „architekstualność” służy Balbusowi do wyodrębnienia pola, w którym każdy tekst staje się modyfikowalnym prototypem gatunku, wykorzystującym do zbudowania swojej struktury różne (niekiedy sprzeczne) elementy zaczerpnięte z tradycji. Genologia okazuje się tym samym pewną wariacją na temat teorii intertekstualności.

W ujęciu poststrukturalnym analizowanym przez Grochowskiego do głosu dochodzi jeszcze jeden element - przygodność. Wittgensteinowskie „pokrewieństwo rodzinne” zakłada bowiem, iż istotą wszelkiego porządkowania będzie stopień podobieństwa ujawniający się przez umieszczanie egzemplarza w coraz to nowych konfiguracjach i kontekstach.

Porządkowanie według podobieństw ma więc charakter dynamiczny i - zależnie od przyjętej perspektywy - pozwala wyodrębniać różne zbiory, pozbawione trwałego umiejscowienia [...]. Podobieństwa ułatwiają zbliżanie i grupowanie obiektów, ale nie mogą służyć ich systematyzacji, gdyż nie nawiązują przejrzystych stosunków podrzędności i nie tworzą trwałych układów pojęciowych. Nie są miarami obiektywnego ładu, lecz przygodnymi efektami porządkowania zjawisk. Ich operacyjnym walorem jest znaczna plastyczność, dzięki której mogą być na bieżąco dopasowywane do przyjętych założeń i celów

W cytowanym fragmencie uwagę przykuwa brak stabilnego umiejscowienia analizowanych egzemplarzy i samych zbiorów. On właśnie wydaje się najściślej przylegać do przypadku Watowskiego archiwum. Znajdziemy w nim teksty, które - w zależności od przyjętych zasad porządkowania lub obranej perspektywy badawczej - będziemy mogli usytuować w różnych gatunkowych zbiorach. Najlepszym przykładem mogą być notatki z Kaiser Hospital: datowanie, a także wielość osobistych, biograficznych odniesień wskazują na ich quasi-dziennikowy charakter; zarazem lektura całego fragmentu dowodzi, że tekst powstaje z perspektywy czasu (nabiera zatem wymiaru pamiętnikarskiego, a nie dziennikowego). Po bliższej analizie znajdziemy w notatkach elementy autofikcji literackiej ${ }^{8}$, podającej w wątpliwość rzetelność faktograficzną zapisu Wata i zbliżającej go

\footnotetext{
${ }^{6}$ Stanisław Balbus, „Zagłada gatunków”, Teksty Drugie 59, nr 6 (1999): 34.

${ }^{7}$ Grochowski, Pamięć gatunków, 55-56 (podkr. - M.K.).

${ }^{8}$ Zob. Anna Turczyn, „Autofikcja, czyli autobiografia psychopolifoniczna”, Teksty Drugie, nr 1-2 (2007): $204-211$.
} 
do ustanowienia w tekście podmiotowości sylleptyczneja: rozdwojonej między kreacją groteskowego świata przedstawionego zaludnionego zamaskowanymi postaciami a próbą podzielenia się doświadczeniem odosobnienia w szpitalnej heterotopii. Przemieszczenie, którego dokonamy, pozwala nam zaobserwować przygodność genologicznego porządku, zmieniającego się dynamicznie wraz z lekturą konkretnych zapisów. Jednocześnie okazuje się, że pozbawione miejsca, atopiczne fragmenty kwestionują mocne osadzenie gatunków: ich granice zostają rozmyte, nie sposób wytworzyć ich jasnych definicji. Notatki z Kaisera - żeby pozostać przy jednym przykładzie - są bowiem zarówno dziennikiem, pamiętnikiem, autobiografią, jak i opowiadaniem posługującym się elementami fikcji. A przynajmniej każdą z tych rzeczy w dowolnym momencie mogą się stać.

Teksty archiwalne domagają się zatem „testowania w różnych kontekstach”10 $\mathrm{i}$ „szerzą się przez krzyżowanie"11; podejmują grę z tradycyjnymi gatunkami, tworząc hybrydy, a jednocześnie zmierzają w stronę realizacji tradycyjnych wyznaczników. Tekst jest zawsze plastyczny: ma swoje ograniczenia, ramy, mieści się w ryzach (na ryzach papieru), a zarazem ma „zdolność [...] do deformacji, do przeobrażenia i rozsadzenia jego [...] pierwotnej formy"12. Jest zatem reprezentantem gatunku i odciskiem indywidualnej podmiotowości, konwencją i idiomem, engramem świata i engramem ciała, gatunkiem i antygatunkiem. Jego przynależność zawsze się stopniuje, nigdy - jest.

Archiwum możemy zatem scharakteryzować jako miejsce niejako predestynowane do generowania gatunków plastycznych, dających się osadzić jedynie w zbiorach rozmytych, o upłynnionych granicach. Obecna w genologii lingwistycznej kategoria zbioru rozmytego, zapożyczona z teorii matematycznej Lotfiego A. Zadeha, jasno i klarownie pozwala na nowo zdefiniować taksonomiczne możliwości genologii ${ }^{13}$. Jak bowiem dowodzi Ernest Januszewski:

Dotychczas powszechnie przyjmowano, że dany element albo należy do zbioru, albo nie. U Zadeha dany element może należeć do zbioru w większym lub mniejszym stopniu, a zatem granice zbioru stają się niejako rozmyte. [...]

Stworzona przez Zadeha teoria zbiorów rozmytych ma za zadanie dostarczyć narzędzi do takiego ujęcia zjawisk niejasnych i niekompletnych, aby znikła potrzeba ich sprecyzowania, zwłaszcza że często jest to po prostu niemożliwe ${ }^{14}$.

Teksty archiwalne nie wpisują się w definicję żadnego gatunku. Ich niejednokrotnie przed-tekstowa, brulionowa forma staje się polem samookreślania, testowania (zgodnie z ideą Wittgensteina) rozmaitych konwencji. Są częścią zbiorów gatunkowych tylko w pewnym stopniu, a ich tożsamość na zawsze musi pozostać „niejasna i niekompletna”. Praca atopii polega bowiem na od-tożsamieniu, od-korzenieniu, ale także na byciu pod-różnym: równocześnie obecnym pod róż-

\footnotetext{
${ }^{9}$ Zob. Ryszard Nycz, „Tropy «ja»: koncepcje podmiotowości w literaturze polskiej ostatniego stulecia”, Teksty Drugie 26, nr 2 (1994): 22-26.

${ }^{10}$ Grochowski, Pamięć gatunków, 62.

${ }^{11}$ Grochowski, 61.

${ }^{12}$ Catherine Malabou, Plastyczność u zmierzchu pisma. Dialektyka, destrukcja, dekonstrukcja, tłum. Piotr Skalski (Warszawa: PWN, 2018), 28.

${ }^{13}$ Zob. Bożena Witosz, Genologia lingwistyczna. Zarys problematyki (Katowice: Wydawnictwo Uniwersytetu Śląskiego, 2005), 99-111.

${ }^{14}$ Ernest Januszewski, „Logiczne i filozoficzne problemy związane z logiką rozmytą”, Roczniki Filozoficzne 55, nr 1 (2007): 109.
} 
nymi adresami, w kilku zbiorach. Nomadyzm gatunkowy tekstu archiwalnego nie oznacza zatem przesuwania go z jednej „szufladki” do drugiej, porzucania kolejnych możliwości gatunkowego przyporządkowania. Sytuuje go raczej w szarej strefie rozmytego zbioru, z której ma on szansę również umykać w stronę takiego czy innego rozwiązania.

\title{
Notka bólowa jako engram ciała
}

Fragmentaryczne, urwane i żadne teksty, o których tu mowa, poszukują zatem swych przygodnych usytuowań w różnych miejscach, a skoro są wszędzie - nigdzie nie możemy ich przydzielić i odnaleźć. Paradoks ten wynika nie tylko z ich trudnej do scharakteryzowania formy (często niemającej wyrazistych cech dystynktywnych), ale także z poczucia ich każdorazowej osobności.

Przyglądając się notesom Wata w archiwum Beinecke Library, odnosiłam wrażenie, że są one wewnętrznie niespójne. Pisarz sporządzał w nich notatki bardzo różnego rodzaju. Niektóre z nich zaś opatrywał datami na wzór zapisów dziennikowych. Podczas kwerend szukałam akurat fragmentów, które teoretycznie mogłyby współtworzyć widmowy korpus Dziennika bez samogłosek, zatem wyłanianie się z notesów urywków quasi-dziennikowych traktowałam jako dobrą monetę. Jednocześnie noty - choć wpisują się oczywiście w większą całość diarystycznych przedsięwzięć Wata kreują przecież zupełnie inny korpus: rozproszonych notek bólowych, w których pisarz dokonuje skrótowej transkrypcji swoich doświadczeń chorobowych. Temat spajający te drobne teksty - choroba - zmusza do zastanowienia się nad ich formalnym i genologicznym pokrewieństwem. Nawet jeśli możemy je traktować jako noty dziennikowe, funkcjonują one także jako ich pewien specyficzny rodzaj, korzystając $z$ form narracji zmedykalizowanej (a więc obecnej w pisarstwie patograficznym $\left.^{15}\right)$, a także lirycznej czy - niekiedy, za sprawą zwrotów do adresata - modlitewno-epistolarnej.

Stanowią zatem materiał do refleksji genologicznej (testując rozmaite zbiory rozmyte), a równocześnie jawią się jako odciski realnego, somatycznego doświadczenia: swoiste engramy piszącego ciała. Jean-Luc Nancy w Corpusie pisze:

\begin{abstract}
"Ciała zapisane" - ponacinane, wyżłobione, wytatuowane, poranione - są ciałami drogocennymi, dlatego zabezpiecza się je i starannie przechowuje tak, jak kody, do których stanowią one dumne engramy. [...] Oto droga, którą należy pójść najpierw - rozpisanie naszego ciała. [...] pozostała po nim jedynie kreska pisma rozpisywanego w sobie samym, nieskończona linia, która biegnie równo z tym, co przełamane, rozdzielone pośród natłoku ciał - linia podziału, odcinająca wszystkie należne jej miejsca: punkty styku, dotknięcia, przecięcia, dyslokacje ${ }^{16}$.
\end{abstract}

Ciało może stać się engramem nie tylko przez znakowanie na skórze, ale także dzięki roz-pisaniu go, przekształceniu w rzeczywistość znakową. Pisanie staje się tu formą ekskrypcji somy w tekst i - tym samym - momentem, w którym tekst wykracza w poza-tekst, w świat doświadczenia. Zetknięcie skóry podmiotu (odczuwanej, w wypadku Wata palącej, niepozwalającej o so-

\footnotetext{
${ }^{15}$ Więcej na temat pisarstwa patograficznego i samego zjawiska literackich patografii zob. Iwona Boruszkowska, Defekty. Literackie auto/pato/grafie - szkice (Kraków: Wydawnictwo Uniwersytetu Jagiellońskiego, 2016) oraz Iwona Boruszkowska, Sygnatury choroby. Literatura defektu w ukraińskim modernizmie (Warszawa: Wydawnictwo IBL, 2018).

${ }^{16}$ Jean-Luc Nancy, Corpus, tłum. Małgorzata Kwietniewska (Gdańsk: Wydawnictwo Słowo/Obraz Terytoria, 2002), 13-14.
} 
bie zapomnieć) ze skórą tekstu (jego tkanką językową, brzmieniową, składniową, uwzględniającą rytm myślenia i oddechu) pozwala zarazem na ich rozdzielenie i jedyną możliwą bliskość.

Gatunkiem, który daje szansę na owo zetknięcie w obcości, w którym ciało piszące ma szansę ujawnić swoją egoiczność oraz niepowtarzalność, jest właśnie efemeryczna i przygodna notka bólowa. Stanowi ona bowiem ślad pamięciowy (ale zapisany niejako fizjologicznie, w samej tkance językowej tekstu) doświadczenia somatycznego. „Ja” ujawnia się w niej jako „odmiana pojedynczego miejsca, sfałdowanie lub gra"17 - opowiada bowiem w formie najintymniejszej (osobistego dziennika nieprzeznaczonego do druku) o nieprzekazywalnym i niepodzielnym bólu, jaki przeżywa. Jednocześnie swój przypadek opisuje niejako „z zewnątrz” - jako przypadek, casus właśnie - przesycając swoją narrację terminami medycznymi (nazwami leków, wyliczeniem dawek). Jak pisze Nancy: „Ego sum tym wgięciem lokalnej odmienności, za każdym razem takiej a takiej; zdarzającej się tylko raz (ile razy jeszcze w tym «jednym» razie? ile artykulacji w tej «jednej»?), a nawet jestem tym akcentem, tym tonem"18. Notka bólowa traktuje o doświadczeniu powtarzalnym (ból towarzyszy Watowi bezustannie, a procedury zażywania leków są zawsze do siebie zbliżone), ale każdorazowo innym (odpowiedź ciała zawsze pozostaje odmienna, niemożliwa do naśladowania). Zatem notki będą do siebie podobne w formie (ustanawiając gatunek), a zarazem w każdej dostrzeżemy inny engram, ślad innego zdarzenia. Derridiańskie „za-każdym-razem-tylko-jeden-raz" ${ }^{\prime 19}$ opisuje najlepiej tę paradoksalną sytuację przynależności i nowości.

W niniejszym tekście nie sposób zaprezentować całego spektrum notatek Wata, których pokrewieństwo z notką bólową byłoby widoczne. Chciałabym jednak, analizując przykładowy fragment $\mathrm{z}$ notesu prowadzonego w latach 60., pochodzący z dnia 8 grudnia, pokazać, w jaki sposób doświadczenie bólowe ma szansę odcisnąć się w języku, pozostawiając w nim nieusuwalny ślad.

\section{$8 / 12$}

Oto ogólna zasada: każdy wiersz, a więc wszelki wiersz, staje na straży zapisu jakiejś daty, tej określonej daty, na przykład „20 stycznia”. Ale, na przekór prawu, przykład pozostaje niezastępowalny. Tym, co musi zostać przynależne straży, inaczej mówiąc - prawdzie każdego wiersza, jest właśnie sama niezastępowalność: przykład daje przykład tylko wtedy, gdy nie może go zastąpić żaden inny. Ale już tym samym daje on przykład, i to jedyny, jaki można dać - że jest jedyny ${ }^{20}$.

W Szibbolecie dla Paula Celana Derrida upomina się o datowany wiersz - zanotowany pod swoją własną datą, niepowtarzalny, a zarazem wpisany w koło wiecznie odnawiającego się kalendarza. Wiersz jednocześnie zatem jest nie-i-powtarzalny, zdarza się jako prototyp gatunku. Zasięgu procesu datowania nie powinniśmy jednak ograniczać do liryki - notki z archiwum Wata wpisują się bowiem także w wyobrażenie tekstu datowanego, posiadającego swój „20 stycznia”.

Opatrywanie datą ustanawia ich radykalną pojedynczość, wchodzącą w kolizję z ewidentną powtarzalnością bólowego doznania. Data staje się - zgodnie z ekonomią Derridy - darem²

\footnotetext{
${ }^{17}$ Nancy, 25.

${ }^{18}$ Nancy, 26.

${ }^{19}$ Jacques Derrida, Szibbolet dla Paula Celana, tłum. Adam Dziadek (Bytom: „FA-art”, 2000), 14.

${ }^{20}$ Derrida, 9.

${ }^{21}$ Zob. Derrida, 12.
} 
gdyż wyzwala z jednostajności świata choroby, w którym wszystkie dni zlewają się w homogenicznym doświadczeniu cierpienia. Watowskie datowanie potraktować więc należy jako wynurzenie się, wydobycie konkretnego momentu z uniwersum nieustannego bólu.

Zgodnie z tą ideą chciałabym wyodrębnić spośród innych jedną datę - 8 grudnia - i przeczytać zapisany wówczas fragment:

$8 / 12$

Dzisiaj miałem przedsmak śmierci mojej, najlepszej z możliwych. Noc była okropna, wziąłem Eufilinę na noc, było mi tak jakoś wyjątkowo po niej (po 20 już minutach) że wbrew zwyczajowi 15-letniemu zausnąłem bez zwykłych środków usypiających. Coprawda było to 36 godzin po zastrzyku morfiny (+ Papaweriny), którym tym razem podziałał już tak strasznie, że postanowiłem skreślić z mojej farmakopei zastrzyki morfinowe, raz na zawsze (brałem je zresztą b. rzadko, z niechęcią głęboką i z coraz gorszym skutkiem) i wprawiła mnie w stan stałej zin godzinnej senności. Na tym tle Eufilina (przecież pochodna morfiny) w czopku działała tym mocniej, nie tyle euforycznie, ale uspokajała jak nic innego raptownie centralny system nerwowy, niestety już na krótko (1-1²/2 godziny, a musiałem przestrzegać 4-5 godzinnych przerw, aby jej działanie nie zmalało).

No i obudziłem się o 3ej wyspany, ale z bólami naturalnie. Wziąłem drugą Eufilinę - ale tym razem zamiast uśpić ożywiła mózg, w coraz szybszych obrotach. Co mi się nie układało w głowie. Ale perspektywa dnia jutrzejszego z niespaniem od 3ej przerażała mnie, lęk przed jej konsekwencjami, całą świtą bólów, niedowładów, podrażnień, opresji, złowrogich myśli! Więc o 3.10 wziąłem wedle ostatniego rytuału: szklaneczkę Passifloryny + tylko jeden Mogadon. Po $1 / 2$ godzinie drugi tylko jeden 1 Litrium + Litrium. Mózg pracuje na obrotach, które mnie męczą, ba niszczą, bóle wracają. Więc o 5.30 zdecydowałem się na Nembutal jeden. Bez skutku, niestety. O 6ej drugi Nembutal, ze strachem przed jutrzejszymi konsekwencjami zatrucia. Zasnąłem jak ołów rzucony na dnie wód głębinowych, zausnąłem, ogo zatkawszy uszy już o 3ej, szczelnie. O 11 obudziło mnie spojrzenie Oli niemrawej. W strasznym stanie. Bóle moje + silny ból w potylicy + odrętwienie, ple + światłowstręt. Kąpiel. O 13 wziąłem Eufilinę. Znów łosło uspokojenie i bóli i nerwów. Nieomal błogość. Śniadanie na fotelu. Rozmowa normalna. Potem Ola, kochana czuła żona Өla krząta się w łazience. Pi Czytać nie mogę ale dobrze mi w fotelu. Potem bóle powracają. Potem czuję - boleśnie - jak krew stopniowo przestaje krążyć. Drętwienie. Głowa opada na bok, ręka z notatnikiem zwisa, nogi drewnieją, jestem z bólem. Tułów ciężki zsuwa się i śpię/nie śpię. Powieki opadają. I znów mnie budzi z odrętwienia wzrok Oli i jej zaniepokojone pytania. Z trudem, wysiłkiem, wstaję, odwracam głowę, młynkuję rękami, pocieram twarz, zamykam i otwieram powieki, chodzić po pokoju nie mogę: bóle, więc powlokę się na tapczan, podnoszę, opuszczam nogi, poruszam palcami, pocieram kark plecy, obracam oczyma, piję mocną kawę. Do następnego Eufilinu minimum 1⁄1/2 godziny, $1 \frac{1}{2}$ godziny bólów dotkliwych. Ale spisuję. Bo chyba tak kiedyś umrę, $w$ fotelu, $\mathrm{z}$ zaniku ubytku krążenia krwi, tak będzie najlepiej. Umrz Byle nie w nienawistnym łóżku. W bólach niestety, i Bóg wie jakich, bo i one zmieniły się. Po 15 latach przypiekania twarzy i nogi, teraz - dodatkowo - straszne ecorché; obdzieranie ze skóry. Może będzie gorzej, o wiele gorzej. Ale - z bólami może, wbrew usnę bólom, dzięki bólom, których przytomnie znosić już się nie da, być może usnę $\mathbf{V}$ Co dalej wielki Boże

V I Ola, Andrzej może będą myśleli, że usnąłem bez bóli, co przecież jest możliwe? ${ }^{22}$

\footnotetext{
${ }^{22}$ Beinecke Rare Book \& Manuscript Library (New Haven), Aleksander Wat Papers (GEN MSS 705), Series II: Writings, Box 31, Folder 730.
} 
Notka z 8 grudnia została zapisana w pomarańczowym notesie marki Rhodia (skądinąd jest to model najczęściej używany przez Wata); pisarz nie trzymał się jednak rygorystycznie wyznaczonych przez papier kratek, jego litery są ścisłe, charakter pisma stosunkowo czytelny. Możemy zaobserwować dość znaczące ścieśnienie pisma (interlinia wydaje się mniejsza) we fragmencie „więc o 3.10 ... śpię/nie śpię”; kiedy Wat rozpoczyna zapis na nowej stronie, interlinia znów jest nieco większa. Biorąc pod uwagę, że opisany tu zostaje cały dzień bólowy (rozpoczynający się nad ranem, około godziny trzeciej), zakładamy, że notka powstaje w momencie słabnięcia czy chwilowego wygasania bólu po południu tego samego dnia. Wskazuje na to również urwana forma, zaznaczająca chwilę, w której pisanie znów staje się niemożliwe lub trudne ze względu na nasilające się dolegliwości somatyczne. Wat umieszcza też w notce kilka dopisków (na marginesie lub wprowadzonych do tekstu „ptaszkiem”, w transliteracji oznaczonym literą $\mathbf{V}$ ), co pozwala na dwojaką interpretację: albo dokonuje on natychmiastowej korekty tekstu (przeczytawszy go jeszcze raz w momencie uznania go za zakończony), albo dopisuje marginalia niejako jednocześnie z kolejnymi zdaniami, uzupełnia swój tekst na bieżąco, kiedy tylko pojawia się nowa myśl. Urwane zakończenie sugeruje sensowność drugiego założenia - notka ma bowiem charakter natychmiastowy, jest wyimkiem poczynionym w drobnym wycinku czasu, kiedy pisarz jest w lepszej kondycji. Do tekstu raczej się nie wraca; po rekonstrukcji stanu somatycznego z początku dnia notka przybiera formę zapisu momentalnego, sygnalizowanego zmianą rytmu zdań i pojawieniem się czasu teraźniejszego.

Charakterystyczna wydaje się swoista podwójność zapisu: rozpoczyna się on na wzór noty w pamiętniku (przeszłość jest rekonstruowana za pomocą stylu literackiego), by następnie inkorporować elementy zapisu dziennikowego (skupienie na chwili obecnej, rozluźnienie składni, pojawienie się znaków ułatwiających notowanie i skrótów, np. „+ Papaweriny” lub „o 3ej wyspany”), a wręcz zaczyna przypominać dziennik choroby (koncentracja na przyjmowanych dawkach leków i symptomach) wchodzący w skład współtworzonej przez pacjenta dokumentacji medycznej.

Niezborność stylistyczno-gatunkowa ujawnia się w zestawieniu dwóch pierwszych zdań. Właściwie tylko otwierająca tekst fraza sugeruje, że będziemy mieli do czynienia z próbą uniwersalizacji opisywanych dalej doświadczeń, włączenia ich w indywidualnie kształtowaną filozofię śmiertelności znaną nam choćby z poezji Wata.

Dzisiaj miałem przedsmak śmierci mojej, najlepszej z możliwych.

Rytm zdania zostaje tu zbudowany przy użyciu inwersji: posłużenie się formułą „śmierci mojej” zamiast "mojej śmierci” sprawia, że w miejsce jednego zestroju akcentowego wkraczają dwa, wybijając mocny rytm pierwszego członu intonacyjnego:

\section{$/{ }_{-}\left|+I_{-}\right| / I_{-} \mid I_{-}$}

Przy dokładnej analizie tego członu dostrzeżemy narastanie napięcia: podkreślony zostaje czas, następnie fraza nabiera rozpędu, by stonować się i „równym krokiem” zmierzać w stronę dominanty. „Śmierci mojej” staje się niejako marszem funeralnym, przeprowadzającym nas na drugą stronę frazy. W jej części opadającej - równie regularnej, z akcentem padającym idealnie na środku trzysylabowych zestrojów - znajdujemy ukojenie: dowiadujemy się bowiem, iż 
byłaby to śmierć najlepsza z możliwych, groza zostaje jej odebrana, a w jej miejsce pojawia się majestatyczność, spokój, zgoda na los. Otwierające zdanie wydaje się na wskroś przemyślane - z harmonijnie rozłożonymi akcentami, stanowi frazę idealną. Następujące po nim wypowiedzenie -

Noc była okropna, wziąłem Eufilinę na noc, było mi tak jakoś wyjątkowo po niej (po 20 już minutach) że wbrew zwyczajowi 15-letniemu usnąłem bez zwykłych środków usypiających

- wyłamuje się zaś z owego doskonałego wznosząco-opadającego frazowania. Występują w nim właściwie dwie frazy, porządkowane raczej za pomocą subkodu ekspresywnego. W pierwszej, „noc była okropna”, dominantą staje się słowo „noc” - znów akcent pada na porę, ale tutaj może mieć ona wymiar symboliczny: noc to czas, w którym pisarza dopada ból, nie pozwalając mu spać i wypocząć. To także czas lęku i oczekiwania na odmianę losu: zarazem strachu i nadziei. Ów stan napięcia zostaje podkreślony w budowie drugiej frazy. Nie potrafi ona bowiem znaleźć jednej antykadencji; jest przez Wata kilkakrotnie rozpoczynana („wziąłem...”, „było mi”, „po 20 już...”, „że wbrew...”), ale rozładowuje ją dopiero człon „usnąłem bez zwykłych środków usypiających". Taka struktura sugeruje wielokrotne zbieranie się do snu, podejmowanie prób zaśnięcia. Jednocześnie wskazuje na galopujące myśli - każda poprzednia domaga się bowiem dookreślenia (nazwania leku, podkreślenia jego wyjątkowości, a potem szybkości jego działania), a nawet dookreślenia niejako stopniowalnego (najpierw dodanego po przecinku, a potem w parenetycznym nawiasie). Intonacyjny chaos, który wprowadza Wat, zostaje dodatkowo wzmocniony rozluźnieniem semantycznym (elementy mowy potocznej - „tak jakoś”) i stylistycznym (powtórzenia: noc, zwyczajowi, zwykłych). Drugie zdanie wprowadza nas zatem w świat zupełnie innej, niemożliwej do podporządkowania żadnym rygorom rytmiki bólu, który wywołuje potoki słów i galopadę myśli - wszystko to, co Wat w Dzienniku bez samogłosek nazwie logoreą:

i tyle logorei, bo pisałem tylko w okresach euforii pijanej między atakami przystępami choroby i to, co moich słuchaczy zastanawia, zaciekawia, a nawet fascynuje, tonie w przeciętnych nawałnicach przeciętności werbalnej, gdy jestem sam na sam, sam ze sobą, gdy czyiś uważny wzrok nie trzyma mojej logorei ${ }^{23}$.

Kolejne zdania będą się w niej zanurzać i szukać z niej wyjścia, tworząc dynamiczną i pełną napięć strukturę rytmiczną składającą się z naprzemiennych „nawałnic werbalnych” i lakonicznych komunikatów.

Przykładem nieutrzymanego w ryzach słowotoku mogą być z jednej strony fragmenty o rozluźnionej składni, z drugiej zaś wypowiedzenia enumeracyjne:

Coprawda było to 36 godzin po zastrzyku morfiny (+ Papaweriny), który tym razem podziałał już tak strasznie, że postanowiłem skreślić z mojej farmakopei zastrzyki morfinowe, raz na zawsze (brałem je zresztą b. rzadko, z niechęcią głęboką i z coraz gorszym skutkiem) i wprawiła mnie w stan stałej zin godzinnej senności.

\footnotetext{
${ }^{23}$ Aleksander Wat, Dziennik bez samogłosek, transkrypcja i oprac. Michalina Kmiecik (Kraków: Wydawnictwo Uniwersytetu Jagiellońskiego, 2018), 270.
} 
$\mathrm{Z}$ trudem, wysiłkiem, wstaję, odwracam głowę, młynkuję rękami, pocieram twarz, zamykam i otwieram powieki, chodzić po pokoju nie mogę: bóle, więc powlokę się na tapczan, podnoszę, opuszczam nogi, poruszam palcami, pocieram kark plecy, obracam oczyma, piję mocną kawę.

W pierwszym cytacie widać nie tylko, że wypowiedzenie ulega rozciągnięciu i wydłużeniu. Strategia odchodzenia od harmonijnych uporządkowań obecna w analizowanym już drugim zdaniu notki, tutaj przybiera na sile. Wat znów posługuje się wtrąceniami i skrótami („+ Papaweriny”, „brałem je zresztą b. rzadko...”), uzupełnia je jednak rozbijaniem jasnych związków składniowych („postanowiłem skreślić z mojej farmakopei zastrzyki morfinowe, raz na zawsze [...] i wprawiła mnie w stan”). Metafora „farmakopei” zyskuje zatem wyjątkowo wyraziste znaczenie - notka bólowa staje się tekstem quasi-pasażowym, zapisem wędrówki po meandrycznym świecie choroby i substancji uśmierzających jej symptomy. Elżbieta Rybicka, definiując kategorię pasażu tekstowego w odniesieniu do tekstów miejskich, zwraca uwagę na istotny z naszego punktu widzenia rys tego pojęcia: „pochodzący z francuskiego passage to tyle co przejście, przechodzenie [...]. Przejściowość (już w znaczeniu bardziej figuratywnym) może stać się zasadą konstrukcyjną"24. Wat w swojej notce przechodzi płynnie przez kolejne stadia farmakologicznej odysei; wylicza objawy, którym trzeba przeciwdziałać, i reakcje, jakie wywołują podejmowane przez niego kroki. Zarówno enumeracja jako podstawowa strategia strukturująca zapis, jak i znakowanie tekstu kolejnymi nazwami leków oraz dawek zmuszają nas, by traktować notkę jako pasaż - przejście między kolejnymi stacjami cierpienia, będące jednocześnie wąską linią - linią graniczną - sytuującą ciało zawsze pomiędzy wnętrzem (ciemnym, zasklepionym w nieprzekazywalnym doświadczeniu bólowym) a zewnętrzem (wszelkimi próbami uśmierzenia bólu, przedostania się do ciała, odzyskania go dla świata).

Ciała nie mają miejsca: ani w dyskursie, ani w materii. [...] Ciała mają miejsce na granicy (choć samo to powiedzenie jest już idealizacją), o ile ich miejscem jest linia graniczna: granica zewnętrzna krawędź, przecięcie tego, co obce z tym, co ciągłe w obszarze sensu, rozłam w ciągłości materii. Otwarcie, nieciągłoś ́́ ${ }^{25}$.

Rozpisywanie ciała, na jakie decyduje się Wat w notatnikach, sytuuje go w ciągłości dyskursu. Regularnie sporządzane notatki mogłyby stanowić korpus patografii; sama metafora farmakopei pokazuje zaś, że pisarz próbuje dostrzec związek między swoim idiosynkratycznym przeżywaniem a tradycją - stąd nawiązanie do motywu Odysei. Jednocześnie enumeracja poświadcza, że pojedyncza notka stanowi każdorazowo inną konfigurację zdarzeń i przeżyć. Powtarzalność miesza się tu z odstępstwem od reguły; nieregularność zapisów i przypadkowość pojawiających się dat tworzą zaś obraz chimeryczny i zależny od nieznanych nam czynników. Granica, na której sytuuje się tekst Wata, wyzwala go od obowiązku przyporządkowania i dookreślenia swojego miejsca (i miejsca tworzonego zapisu). Poetyka dowartościowująca potoczność i brak rygorów gramatycznych, a także wyliczeniową strukturę staje się tym samym „anatomicznym znakiem «siebie»"26; linia podziałów, rozdzieleń i granic nie zmierza do rozczłonkowania Watowskiego korpusu, ale raczej pozwala przemieszczać go w rozmaite przestrzenie i na nowo interpretować:

\footnotetext{
${ }^{24}$ Elżbieta Rybicka, Modernizowanie miasta. Zarys problematyki urbanistycznej w nowoczesnej literaturze polskiej (Kraków: Wydawnictwo Universitas, 2003), 166-167.

${ }^{25}$ Nancy, Corpus, 18.

${ }^{26} \mathrm{Nancy}, 76$.
} 
Bardziej niż z anatomią rozczłonkowania mamy tu do czynienia z anatomią obrachunku, to jest $\mathrm{z}$ anatomią konfiguracji, modelowań, a dokładniej: stanów-ciała, sposobów bycia, postaw, oddechów, usiłowań, odrętwień, boleści, przyjemności ${ }^{27}$.

Wat dąży do scalenia doświadczenia swojej cielesności; próbuje przywrócić sobie spoistość za pomocą leków, ruchów, podejmowanej aktywności. Pisanie jest dla niego formą i znakiem odzyskiwania kontroli. Nawet w tej notce próbuje to zaznaczyć: „Pi Czytać nie mogę ale dobrze mi w fotelu” - inicjujące zdanie i przekreślone na rzecz czytania „pi” zdaje się odsyłać właśnie do aktu notowania. W tamtej chwili jeszcze trudno sięgnąć po długopis, ale już moment później Wat doda: „Ale spisuję. Bo chyba tak kiedyś umrę”. Spójnik „ale” rozpoczynający zdanie sugeruje, że Wat zapisuje „pomimo” bólu i niewygody, „pomimo” lęku, że w nic się to nie złoży. Analogicznych śladów językowych, oznaczających nieustannie ponawiane próby, znajdziemy w notkach więcej:

Potem Ola, kochana czuła żona Өla krząta się w łazience. Pł Czytać nie mogę ale dobrze mi w fotelu. Potem bóle powracają. Potem czuję - boleśnie - jak krew stopniowo przestaje krążyć.

Powracające „potem”, wybijane zawsze na początku zdania, sugeruje monotonię i uporczywość doświadczeń bólowych. Staje się też wstępem do kolejnego ataku logorei. Krótkie równoważniki zdań i zdania pojedyncze przeplatają się tu z rozbudowanymi enumeracjami. Taktyka Wata, by przyspieszać i zwalniać rytm swojego pisma, wydaje się odbiciem przypływu i odpływu sił: ruch cierpienia przypomina falę, z punktem kulminacyjnym i wyciszeniem, zwiastującym jedynie kolejne wynurzenie się i kolejny atak. Wyliczenie (zapisane też w pewnym momencie przy użyciu znaku dodawania) stanowi najszybszą strategię wypowiedzenia wszystkich objawów. Widać jednak w jego narastaniu i budowaniu mozół, podkreślony niepoprawnym użyciem znaków przestankowych: „Z trudem, wysiłkiem, wstaję”. Przecinek przed „wstaję" sugeruje, że Wat dalej będzie wymieniał, jak bardzo ciężko jest mu wykonywać rozmaite czynności - nie spodziewamy się, że następne słowo będzie czasownikiem. Użycie go (podbite aliteracją) nadaje wyrazowi „wstaję" zupełnie inną konotację: zostaje w niego od razu wpisany znój choroby, który czytelnik może poczuć na własnej skórze, kiedy Wat rozpoczyna litanię aktywności służących pobudzeniu ciała do sprawniejszego działania. Większość z nich rozpoczyna się od przedrostka „po-” (powlokę, podnoszę, poruszam, pocieram), oznaczającego powtarzanie czynności przez jeden podmiot względem różnych przedmiotów. Mamy więc pacjenta, który wielokrotnie pobudza różne części ciała: jest jednocześnie podmiotem i przedmiotem swojej aktywności. Jego soma zaś zostaje rozbita na kawałki poddawane - każdy z osobna - ożywiającym zabiegom.

Enumeracja wydaje się zatem zabiegiem ważnym z jeszcze jednego powodu. Jej stosowanie wydobywa bowiem (na wzór strategii datowania) pojedyncze doznanie z całej fali napływających elementów. Wat osiąga dzięki niej efekt jednoczesnego wezbrania i fragmentacji. Najlepiej obrazują to różnice w kreowaniu ciągów: raz są to szeregi akumulatywne objawów, podane w sposób najbardziej zobiektywizowany i odpodmiotowiony, łączone plusami („Bóle moje + silny ból w potylicy + odrętwienie, ple + światłowstręt”); innym razem asyndetonowe potoki 
drobnych aktywności przeciwdziałających objawom („poruszam rękami, pocieram twarz...”). Za każdym razem enumeracja jest tylko pewną - zdawałoby się przypadkową - konfiguracją zdarzeń czy symptomów; można je dowolnie wysuwać z szeregu i w nim umieszczać. Są dni, kiedy konstelacja objawów wygląda inaczej - każdy z nich stanowi przecież ruchomy, możliwy do wyizolowania element. Jednocześnie - i warto to podkreślić - różne sposoby zapisu sugerują odmienny stosunek do samej choroby i jej odczuwania. Fizyczne dolegliwości pisarz próbuje oddzielić od podmiotowej perspektywy - wyizolować je niejako podwójnie. Strategie oporu wobec bólu zaś pragnie jak najmocniej osadzić w ramach swojej świadomości; są one dowodem na to, że się nie poddaje, że wciąż próbuje sobie swoje ciało podporządkować. Czyni to, akcentując jego rozczłonkowanie, czyli „lokalność. Tylko za pomocą konkretnych mikrodziałań może budować poczucie kontroli: zostaje mu zatem delikatne poruszanie nogami, młynkowanie palcami, poruszanie gałkami ocznymi. Sensu własnego ciała nie doświadcza się tu w ogólności; zawsze jest on silnie spartykularyzowany, możliwy do odczucia przez moment, w błysku. Fluktuacje bólu nie pozwalają się do niego przywiązywać.

Ból zresztą - ukryty w różnych znakach, wysyłający wiele sygnałów - organizuje cały tekst i pozwala postrzegać ten zbiór chimerycznych notek jako pewną genologiczną całość. Wat podkreśla to zresztą w końcówce omawianego wyimka:

Ale - z bólami może, wbrew usnę bólom, dzięki bólom, których przytomnie znosić już się nie da, być może usnę.

W pierwszej redakcji pisarz unika słowa „ból”. Wydaje się, że zdanie, które zamierza zanotować, będzie krótsze. Ból przenika je jednak i wkrada się w wielu formach w każdą jego część, tworząc poliptotonową strukturę. Rozrasta się niczym - nomen omen - polip: pomnażając i intensyfikując negatywne doświadczenia, wpychając Wata w pułapkę bez wyjścia. Z niej jednak wyłania się osoba zarówno przerażona, jak i krucha, troskliwa. Wtrącając zdanie o żonie oraz synu, Wat udowadnia, że doświadczenie wszechogarniającego cierpienia nie musi oznaczać degradacji czującego „ja”, które ostatnim wysiłkiem woli zadaje pytanie:

I Ola, Andrzej może będą myśleli, że usnąłem bez bóli, co przecież jest możliwe?

Do kogo zostaje ono skierowane? Czy zapowiada już ostatnią, zerwaną apostrofę do Boga? Zdanie ewidentnie dzieli się na dwie frazy; „co przecież jest możliwe?” staje się otwarciem nowej, kolejnym etapem rozważań, pytaniem skierowanym w pustkę, ku instancji, która nie zareaguje i nie przyniesie pocieszenia. Notka przeradza się tym samym w rodzaj cichej, naszeptanej głosem prawie już niesłyszalnym modlitwy o śmierć „najlepszą z możliwych”. Uruchomienie kodu literackiego w zakończeniu tekstu (w apostrofie do Boga) pozwala zatoczyć koło. To, co uważaliśmy za zerwane zakończenie, okazuje się - paradoksalnie - klamrą pozwalającą włączyć niby-dziennikowy wpis w korpus tych tekstów literackich, które podejmują kwestię niemożliwej do wysłuchania czy wypowiedzenia modlitwy. Staje także po stronie literackiego świadectwa: prób rozpisania ciała i jego bólowych doświadczeń tak, aby można było dotknąć ich poprzez lekturę, śledzenie duktu pisma i rytmu zdań. Zalegające w ostatnim, niezakończonym nawet pytajnikiem, zdaniu milczenie nie przekreśla komunikacji - ono ją ustanawia. Jak słusznie bowiem pisze Nancy: 
O czym nie można już mówić, o tym nie powinno się milczeć. Należy wciąż wywierać nacisk na mowę, język i dyskurs tak, aby wreszcie zwarły się one z ciałem, bo chociaż kontakt z nim pozostaje niepewny, niemiarowy i wymykający się, to przecież jest on również nieustępliwie ciągły ${ }^{28}$.

Notka bólowa, tak jak próbuję ją zdefiniować, ma zatem zawsze charakter quasi-apostrofy. Słowa, choć pozornie skupione na rekonstrukcji doświadczenia podmiotu piszącego, autoanalityczne, intymne, mają trafić do słuchającego i współodczuwającego „ty”. Robienie miejsca dla bólu w języku jest bowiem próbą zakomunikowania obecności ciała, jego poruszeń i dramatów - wypowiedzenie go zaś ma służyć dawaniu świadectwa o istnieniu, stanowić transfigurację somatyczności w semiotyczność ${ }^{29}$.

Ciało jest jednak każdorazowo inne, do siebie niepodobne, choć przecież wciąż to samo. Jego doświadczanie polega na jednoczesnym odczuwaniu ciągłości i różnicy: czujemy się bowiem ze sobą tożsami, wiedząc, że nieustannie się zmieniamy. Narzucając na tekst powtarzalny genologiczny schemat, upodabniając do siebie poszczególne wpisy, fragmenty i noty, Wat scala swoje doświadczenie i nadaje mu sens. W pisaniu odnajduje „śmierć najlepszą z możliwych”: jest w nim spokój wyliczenia kolejnych etapów i zmian somatycznych, precyzja w analizowaniu środków zaradczych, chłód medycznych terminów. Jest także, ujawniany w falującym, układającym się czasem niczym pulsujący zapis EKG rytmie zdań, engram konkretnego ciała - odciśniętego w danym dniu, godzinie, momencie. Zapis bólowy potrafi różnić się od siebie drobnostkami, załamaniami intonacyjnymi, odmienną konstrukcją zdań. Pozwala on pochwycić pewien konstans doświadczenia cierpienia, a jednocześnie daje szansę, by zachować jego absolutną pojedynczość. Jak pisał Derrida:

from one repetition to the next, a change had insinuated itself into the relationship between the two initial utterances. The punctuation had been slightly modified, as had the content of the second independent clause. Theoretically, this barely noticeable shift could have created a mutual independency between the interpretative alternative ${ }^{30}$.

[między jednym a drugim powtórzeniem, do relacji pomiędzy początkowymi wypowiedziami wślizgnęła się zmiana. Ortografia została lekko zmodyfikowana, podobnie jak treść drugiej niezależnej klauzuli. Teoretycznie, to ledwie zauważalne przesunięcie mogło stworzyć wzajemną niezależność interpretacyjnej alternatywy - tłum. moje].

Zmiana, będąca sygnałem wysyłanym przez ciało pod określoną datą (przez właśnie ten, a nie inny przypadek), wkrada się do tekstu niepostrzeżenie, nie zaburzając jego spoistości. Ta ostatnia pozwala mu wciąż rezydować w uniwersum prawa gatunku. $\mathrm{Z}$ punktu widzenia czytelnika najważniejsze pozostają jednak odciski „ledwie zauważalne”, ślady istnienia pojedynczego, przesuwającego swój tekst w różne miejsca na polu literackich odniesień i schematów, oświetlającego go za każdym razem (za pomocą każdego brzmienia, rytmiki zdań) inaczej i na nowo. Rozmowa ciała z ciałem odbywa się bowiem zawsze podwójnie: w języku, który już rozumiemy, i w języku, którego musimy się codziennie na nowo uczyć.

\footnotetext{
${ }^{28}$ Nancy, 54-55.

${ }^{29}$ Zob. Adam Dziadek, Projekt krytyki somatycznej (Warszawa: Wydawnictwo IBL, 2015), 20.

${ }^{30}$ Jacques Derrida, „The Law of Genre”, tłum. Avital Ronell, Critical Inquiry 7, nr 1 (1980): 58.
} 


\section{Bibliografia}

Antoniuk, Mateusz. „Proces tekstotwórczy jako najpiękniejszy przedmiot badań, którego nie ma”. W Pracownia Herberta. Studia nad procesem tekstotwórczym. Zredagowane przez Mateusz Antoniuk, 11-26. Kraków: Wydawnictwo Uniwersytetu Jagiellońskiego, 2017.

Balbus, Stanisław. „Zagłada gatunków”. Teksty Drugie 59, nr 6 (1999): 25-39.

Boruszkowska, Iwona. Defekty. Literackie auto/ pato/grafie - szkice. Kraków: Wydawnictwo Uniwersytetu Jagiellońskiego, 2016.

---. Sygnatury choroby. Literatura defektu w ukraińskim modernizmie. Warszawa: Wydawnictwo IBL, 2018.

Derrida, Jacques. Gorqczka archiwów. Przetłumaczone przez Jakub Momro. Warszawa: Wydawnictwo IBL, 2016.

---. Szibbolet dla Paula Celana. Przetłumaczone przez Adam Dziadek. Bytom: „FA-art”, 2000.

---. „The Law of Genre”, Przetłumaczone przez Avital Ronell. Critical Inquiry 7, nr 1 (1980): $55-81$.

Dziadek, Adam. „Aleksander Wat w Beinecke Library w Yale”. Teksty Drugie, nr 6 (2009): 251-258.

---. Projekt krytyki somatycznej. Warszawa: Wydawnictwo IBL, 2015.

Grochowski, Grzegorz. Pamięć gatunków. Ponowoczesne dylematy atrybucji gatunkowej. Warszawa: Wydawnictwo IBL, 2018.
Januszewski, Ernest. „Logiczne i filozoficzne problemy związane z logiką rozmytą”. Roczniki Filozoficzne 55, nr 1 (2007): 109-128.

Kmiecik, Michalina. „Zapiski z Kaiser Hospital Aleksandra Wata - fragmenty autobiografii heterotopicznej”. Wielogłos 31, nr 1 (2017): 67-86.

Malabou, Catherine. Plastyczność u zmierzchu pisma. Dialektyka, destrukcja, dekonstrukcja. Przetłumaczone przez Piotr Skalski. Warszawa: PWN, 2018.

Nancy, Jean-Luc. Corpus. Przetłumaczone przez Małgorzata Kwietniewska. Gdańsk: Wydawnictwo Słowo/Obraz Terytoria, 2002.

Nycz, Ryszard. „Tropy «ja»: koncepcje podmiotowości w literaturze polskiej ostatniego stulecia”. Teksty Drugie 26, nr 2 (1994): 7-27.

Rybicka, Elżbieta. Modernizowanie miasta. Zarys problematyki urbanistycznej $w$ nowoczesnej literaturze polskiej. Kraków: Wydawnictwo Universitas, 2003.

Turczyn, Anna. „Autofikcja, czyli autobiografia psychopolifoniczna”. Teksty Drugie, nr 1-2 (2007): 204-211.

Wat, Aleksander. Dziennik bez samogłosek. Transkrypcja i opracowanie Michalina Kmiecik. Kraków: Wydawnictwo Uniwersytetu Jagiellońskiego, 2018.

Witosz, Bożena. Genologia lingwistyczna. Zarys problematyki. Katowice: Wydawnictwo Uniwersytetu Śląskiego, 2005. 


\title{
SEOWA KLUCZOWE:
}

\author{
A R C H I W U M
}

\section{genologia}

\begin{abstract}
ABSTRAKT:
Artykuł skupia się na mikroanalizie jednej z rękopiśmiennych „notek bólowych” Aleksandra Wata (datowanej na 8 grudnia, zachowanej w archiwum pisarza w Beinecke Library). Rozważam zarówno kwestię jej genologicznego przyporządkowania, które - ze względu na fragmentaryczność, wyrywkowość, dziennikowość zapisu (a jednocześnie umieszczenie jej poza ustabilizowaną formą dziennika) - nie zmierza do włączenia jej w żadną większą całość. "Nieprzynależność” notki i innych analogicznych zapisów zdaje się kształtować ich swoistą poetykę. Posiłkując się rozpoznaniami poststrukturalnej genologii i teorią zbiorów rozmytych, proponuję uznać notkę za swoisty gatunek dryfujący, który istnieje w wielu kontekstach genologicznych jednocześnie, tworząc także własną, „pojedynczą” formę. Zainspirowana rozważaniami o cielesności Jean-Luca Nancy’ego oraz krytyką somatyczną Adama Dziadka, chciałabym określić ją mianem „engramu ciała”. Na przykładzie wyizolowanej „notki bólowej” zastanawiam się zatem nad możliwością użycia tej kategorii w kontekście zarówno rekonstruowania genetyki tekstu, jak i dokonywania przykładowej rytmoanalizy prozy.
\end{abstract}




\section{krytyka somatyczna}

\section{Aleksander Wat}

\section{NOTA O AUTORCE:}

Michalina Kmiecik - literaturoznawczyni, pracuje w Katedrze Teorii Literatury i Ośrodku Badań nad Awangardą Wydziału Polonistyki UJ. Autorka książek o historii polskiej oraz europejskiej awangardy (Oblicza miejsca. Topiczne i atopiczne wyobrażenia przestrzeni w poezji Juliana Przybosia, Kraków 2013; Drogi negatywności. Nurt estetyczno-religijny w poezji i muzyce awangardowej w XX wieku, Kraków 2016). Publikowała m.in. w „Tekstach Drugich”, „Ruchu Literackim” czy „Pamiętniku Literackim”. Przygotowała genetyczną edycję zaszyfrowanej wersji Dziennika bez samogłosek Aleksandra Wata (Kraków 2018). Obecnie, wraz z Iwoną Boruszkowską, pracuje nad projektem Style zachowań awangardowych (NCN, Sonata 10). 